\title{
Pemanfaatan Limbah Pelelangan Ikan Jembatan Puri Di Kota Sorong Sebagai Bahan Pembuatan Tepung Ikan
}

\section{Utilization Waste of Castle Bridge Fish Auction in Sorong City As a Material for Making Fish Meal}

\author{
Ahmad Fahrizal ${ }^{1}$ dan Ratna ${ }^{2}$ \\ 1-2 Program Studi Manajemen Sumberdaya Perairan \\ Universitas Muhammadiyah Sorong \\ E-mail : a.fahrizal.ab@gmail.com
}

\begin{abstract}
Abstrak
Kegiatan pelelangan ikan di TPI Jembatan Puri atau PPI Klaligi berlangsung setiap hari demikian juga dengan limbah hasil pelelangan ikan sebagai hasil sampingan terbuang ke daerah sekitar PPI. Penelitian ini diharapkan dapat menekan beban lingkungan yang disebabkan oleh limbah yang berasal dari PPI Jembatan Puri, Kota Sorong. Penelitian ini bertujuan untuk mengidentifikasi limbah yang dapat dijadikan sebagai bahan pembuatan tepung ikan yang bersumber dari limbah PPI. Metode yang digunakan dalam penelitian ini adalah metode eksperimen meliputi pembuatan tepung ikan dan berbahan limbah ikan dari PPI. Berdasarkan hasil identifikasi limbah perikanan di PPI Klaligi ditemukan limbah perikanan berupa limbah ikan tuna yaitu kepala, tulang, sirip, ekor, insang dan isi perut berupa usus. Limbah yang kedua yaitu limbah ikan cakalang berupa sirip, isi perut berupa usus, serta insang. Limbah ikan puri berupa kepala ikan puri, limbah ikan merah berupa sisik, sarta ikan sarden yang memiliki nilai ekonomi rendah. Hasil uji proksimat tepung berbahan limbah ikan pada penelitian ini menunjukkan bahwa tepung berbahan limbah ikan berdasarkan jenis ikan diperoleh kandungan yang berbeda. Dari hasil uji proksimat diperoleh kadar air, abu, lemak, protein, dan karbohidrat. Kandungan sisik ikan laut yang sudah dikeringkan secara umum adalah air $9.81 \%$, abu $25,11 \%$, protein $48,57 \%$, lemak $4,98 \%$, dan karbohidrat $11,46 \%$. Kesimpulan dari hasil penelitian menunjukkan bahwa tepung berbahan limbah ikan berdasarkan jenis ikan tuna, ikan cakalang, ikan teri dan ikan sarden serta sisik ikan kakap merah layak untuk digunakan sebagai bahan pakan berdasarkan kriteria bahan baku meliputi kandungan protein serta ketersediaan bahan untuk pembuatan tepung ikan.
\end{abstract}

Kata Kunci: Limbah Pelelangan ikan, Tepung Ikan, PPI Jembatan Puri Klaligi Kota Sorong 


\begin{abstract}
Fish auction activities at TPI Jembatan Puri or PPI Klaligi take place every day as well as waste from fish auction results as a by-product is wasted into the area around PPI. This research is expected to reduce the environmental burden caused by waste originating from PPI Jembatan Puri, Sorong City. This study aims to identify waste that can be used as material for making fish flour sourced from PPI waste. The method used in this study is an experimental method which includes the manufacture of fish meal and made from fish waste from PPI. Based on the results of identification of fisheries waste in PPI Klaligi found fisheries waste in the form of tuna fish waste namely head, bones, fins, tail, gills and stomach contents in the form of intestines. The second waste is skipjack fish waste in the form of fins, stomach contents in the form of intestines, and gills. The puri fish waste is in the form of a puri fish head, red fish waste in the form of scales, sardines which have low economic value. Proximate test results of flour made from fish waste in this study indicate that flour made from fish waste based on the type of fish obtained different contents. From the proximate test results obtained moisture, ash, fat, protein, and carbohydrate content. The content of marine fish scales that have been dried in general are $9.81 \%$ water, $25.11 \%$ ash, $48.57 \%$ protein, $4.98 \%$ fat, and $11.46 \%$ carbohydrate. Conclusions from the results of the study showed that flour made from fish waste based on tuna, skipjack fish, anchovy and sardines and red snapper scales suitable for use as feed ingredients based on the criteria of raw materials included protein content and availability of ingredients for fish meal making.
\end{abstract}

Keywords: Fish Auction Waste, Fish Flour, PPI Jembatan Puri Klaligi of Sorong City. 


\section{Pendahuluan}

Produksi sektor perikanan Kota Sorong semakin meningkat dari tahun ke tahun yang meliputi sumber-sumber pelagis (ikan teri, layang, selar kuning, lemuru, kembung, tenggiri, cakalang, dan ikan tuna), dan sumber demersal (ikan petek, kurisi, gulama, layur, swanggi, bubara, kerapu, ikan merah), serta sumber lainnya (udang batu, teripang, sirip hiu, udang) yang mencapai 2.390,59 pada tahun 2008 dan meningkat menjadi 3.326,00 ton pada tahun 2011 (DKP Kota Sorong, 2011) dan pada Tahun 2017 mencapai 12.790 ton dengan 99,79\% diantaranya bersumber dari perikanan laut. Ikan yang dihasilkan meliputi sumber pelagis (ikan teri, layang, ikan tetengkek (ikan selar kuning), kembung, tenggiri, tuna, cakalang, tongkol), ikan demersal (ikan kurisi, gulamah, kuwe, kerapu, kakap, bawal, lancam, ikan manyung (ikan sembilang), dan pari lontar), serta sumber lainnya (udang, anakan siput, cumi-cumi) (BPS Papua Barat, 2018; Satwas PSDKP Sorong, 2017).

Sejak diberlakukannya Peraturan Menteri Kelautan dan Perikanan (Permen KP) No. 56 Tahun 2014 tentang pemberhentian perizinan sementara (moratorium) kapal-kapal eks asing oleh Kementerian Kelautan dan Perikanan (KKP) Republik Indonesia (RI) pada tahun 2014, terjadi penurunan pendapatan hingga hilangnya mata pencaharian nelayan. Implementasi kebijakan moratorium dan transhipment tersebut telah berdampak langsung baik secara negatif maupun positif. Salah satu dampak positif dari moratorium di Kota Bitung adalah adanya peningkatan harga jual ikan yang sebelum moratorium berkisar pada Rp. 300.000,-/lima kantong menjadi Rp. 600.000,-/kantong setelah moratorium (Nurlaili, dkk., 2016).

Hasil laut Di Kota Sorong kemudian di daratkan di Tempat Pelelangan Ikan (TPI) Jembatan Puri (Jempur). DKP Kota Sorong (2017) mengatakan bahwa TPI Jempur yang pada tahun 2016 telah berganti nama menjadi Pangkalan Pendaratan Ikan (PPI) Klaligi. PPI Klaligi turut membangkitkan perekonomian masyarakat nelayan dan pengusaha ikan di Kota Sorong dengan menyediakan penampungan ikan (cold storage) yang berdampingan di lokasi PPI. Jumlah tangkapan ikan di Kota Sorong dan sekitarnya berkisar antara 400 ton pada tahun 2013 dengan negara 
sasaran yaitu Thailand, dan Singapura (Dewi dan Ruqyah, 2014). Pada periode Desember 2017- Agustus 2018 pendaratan ikan mencapai $25.734,25$ ton yang meliputi Ikan tongkol, ikan layang, ikan puri, dan ikan kembung (WWF, 2018).

Besarnya hasil perikanan tangkap di Kota Sorong memberi dampak tersendiri bagi lingkungan pesisir di lokasi TPI dan sekitarnya. Sisa-sisa potongan ikan cakalang, tuna dan ikan lainnya bertebaran di sekitar lokasi pelelangan ikan. Banyaknya limbah ikan sebagai hasil kegiatan pelelangan ikan yang bersumber serta ikan-ikan yang memiliki nilai ekonomis rendah menyebabkan limbah ikan menjadi tidak termanfaatkan dan cenderung menimbulkan bau menyengat di sekitar lokasi PPI. Salah satu jenis limbah yang banyak ditemukan di PPI Klaligi yaitu berupa sisa potongan kepala, sisik, tulang ikan, ekor, serta isi perut ikan berupa organ pencernaan seperti usus ikan. Sebagai salah satu hasil dari limbah perikanan yang belum dimanfaatkan dengan baik, sehingga diharapkan dengan adanya upaya pemanfaatan limbah perikanan diharapkan dapat menekan beban lingkungan yang disebabkan oleh limbah dapat dimanfaatkan sebagai bahan pembuatan tepung tulang ikan. Hal ini mendorong peneliti untuk melakukan penelitian yang berjudul "Pemanfaatan Limbah Pelelangan Ikan Jembatan Puri Di Kota Sorong Sebagai Bahan Pembuatan Tepung Ikan" guna menekan dampak pencemaran yang ditimbulkan oleh limbah ikan di TPI Jembatan Puri.

Adapun tujuan dari penelitian ini adalah untuk mengindentifikasi limbah yang sesuai untuk tepung ikan dan untuk memproduksi tepung ikan yang bersumber dari pemanfaatan limbah PPI. Dikarenakan kebutuhan akan tepung ikan (fish meal) masih mengandalkan impor yaitu sebesar 90\% atau setara dengan nilai US\$ 480 juta (Rp. 5,7 Trilliun) (finance.detik.com, 2015), sehingga diharapkan dengan adanya penelitian ini, dapat berkontribusi pada pengembangan tepung ikan dalam upaya menekan ketergantungan penggunaan tepung ikan di Indonesia. 


\section{Metode Penelitian}

\section{Waktu dan Tempat}

Penelitian ini dilaksanakan selama 5 bulan dimulai pada bulan Februari sampai dengan bulan Juli 2018, di Jembatan Puri Kota Sorong, Laboratorium Dasar Fakultas Perikanan Universitas Muhammadiyah Sorong, dan Laboratorium Nutrisi Politeknik Pertanian Negeri Pangkep.

\section{Alat dan Bahan}

Alat yang digunakan selama penelitian diantaranya: mesin penepung, oven, kompor, panci, karung, pisau, baskom, ayakan, timbangan digital. Bahan yang digunakan selama penelitian diantaranya limbah ikan tuna, limbah ikan cakalang, limbah ikan teri/puri, dan limbah ikan sarden, tepung kedelai, tepung jagung, dedak halus, vitamin c, dan minyak ikan.

\section{Metode Pengambilan Data}

Jenis data yang digunakan selama penelitian ini terdiri dari data primer dan data sekunder. Data primer diperoleh dari hasil uji proksimat tepung ikan yang diolah dari limbah ikan di Jembatan Puri, Kota Sorong. Data sekunder diperoleh dari literatur berupa jurnal hasil penelitian terkait, maupun bahan pendukung lainnya.

\section{Tahapan Penelitian}

Tahapan penelitian meliputi persiapan alat dan bahan, diantaranya: 1. Identifikasi limbah ikan; 2. Persiapan sampel limbah ikan yang digunakan dalam penelitian ini adalah limbah ikan Tuna (Thunnus sp.), limbah ikan Cakalang (Katsuwonus sp.), limbah ikan teri (Engraulidae sp.) dan ikan Sarden (Sardinella sp.). Untuk limbah sisik ikan kerapu merah (Lutjanus sp.) menggunakan literatur sekunder; 3. Penepungan bahan limbah ikan (Gambar 1); dan 4. Uji kadar Proksimat tepung berbahan limbah ikan. Pada penelitian ini berfokus pada uji kimiawi yaitu uji proksimat untuk mengetahui kadar protein yang dilakukan dengan metode kjedahl. Untuk mengetahui kadar protein sampel dilakukan dengan beberapa tahap yaitu tahap destruksi, tahap destilasi, tahap 
titrasi, perlakuan blanko, dan perhitungan (AOAC, 1995, dalam Trilaksani, Salamah, dan Nabil, 2006), dan Munthe, dkk., (2016). berikut:

Prosedur pembuatan tepung ikan disajikan dalam bentuk diagram

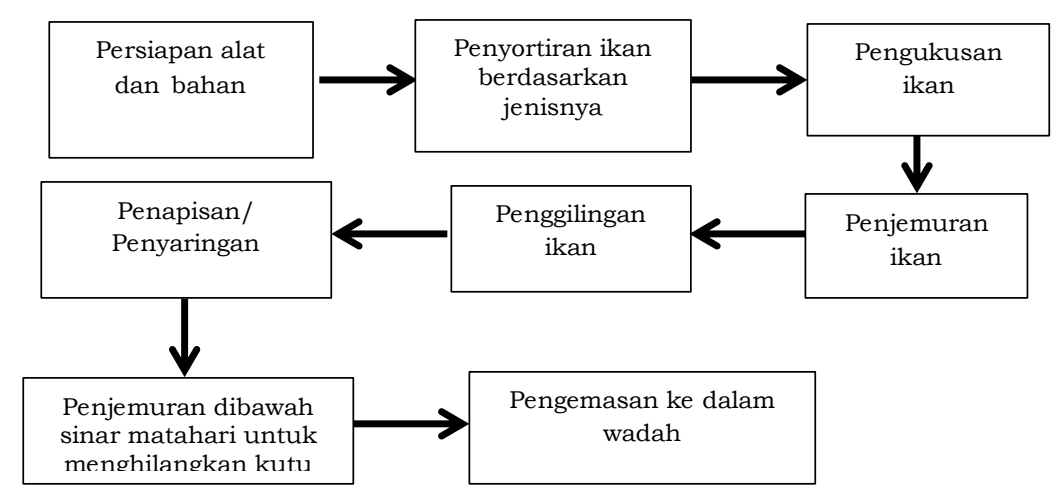

Gambar 1. Diagram Alir Proses pembuatan tepung ikan

\section{Analisa Data}

Analisis data dilakukan secara analisis deskriptif untuk tepung ikan dan pellet yang dihasilkan dan analisis deskriptif kualitatif untuk mengetahui hubungan antara pemanfaatan limbah perikanan dengan upaya mengurangi pencemaran.

\section{Hasil Dan Pembahasan}

\section{Hasil Identifikasi Limbah Ikan}

Berdasarkan hasil identifikasi limbah ikan yang ditemukan di PPI Klaligi diidentfikasi limbah berupa ikan tuna (kepala, tulang, sirip, ekor, insang dan isi perut berupa usus, dan organ lainnya). Limbah yang kedua adalah limbah ikan cakalang berupa sirip, isi perut berupa usus, dan organ lainnya. Ikan puri berupa kepala ikan puri, limbah ikan merah berupa sisik, serta melimpahnya ketersediaan ikan sarden yang cenderung memiliki harga yang relatif rendah.

Menurut Afrianto dan Liviawaty (2005), setidaknya ada lima persyaratan yang sebaiknya dipenuhi dalam pemilihan bahan baku pakan: (1) nilai gizi, pengetahuan tentang nilai gizi pakan sangat berguna karena dapat mesubtitusi/menutupi kekurangan yang dimiliki oleh bahan baku lainnya. (2) mudah dicerna, semakin tinggi nilai ubah bahan 
pakan maka akan semakin sulit untuk di cerna oleh ikan. seperti penggunaan kedelai yang memiliki enzim tripsin inhibitor dapat menurunkan tingkat kecernaan pakan. Salah satu upaya yang dilakukan untuk menghilangkan enzim tripsin inhibitor adalah dengan pemanasan dengan autoklaf pada suhu 140-150 $\mathrm{C}$ selama 2,5 menit. (3) Tidak mengandung racun, bahan pakan yang terpapar racun seperti obat pemberantas hama/pesitisida, buangan industry, hasil aktivitas mikroba, hasil proses oksidasi, atau sisa oli dan bahan bakar pada saat pembuatan pakan, serta penyimpanan pakan yang terlalu lama sehingga aktivitas mikroba, serangga atau proses oksidasi dapat meningkatkan kadar racun pada pakan, (4) mudah diperoleh, bahan baku yang mudah diperoleh dengan harga murah antara lain limbah pasar, limbah rumah makan, limbah industri makanan (seperti pengalengan ikan, pabrik kecap, industri tahu, dan penggilingan peda) dan limbah pertanian menjadi syarat lain karena dapat menekan biaya penyedaiaan bahan baku pakan, dan (5) Bukan merupakan kebutuhan pokok manusia, sehingga tidak terjadi persaingan kebutuhan bahan dan kurang efisien apabila digunakan sebagai bahan baku pakan ikan. Olehnya itu pemanfaatan limbah menjadi bahan baku pakan menjadi alternatif untuk menekan biaya pengadaan bahan pakan.

\section{Analisis Uji Proksimat Bahan Tepung Ikan Berbahan Limbah Ikan}

Tepung ikan adalah ikan atau bagian-bagian ikan yang minyaknya diambil atau tidak, dikeringkan kemudian digiling (SNI 01-27151996/Rev.92). Hasil penelitian yang diperoleh dari bahan tepung ikan yang meliputi uji proksimat dapat dilihat pada Tabel di bawah ini.

Tabel 1. Uji Proksimat Sampel Tepung Berbahan Limbah Ikan Di Jembatan Puri

\begin{tabular}{c|l|c|c|c|c|c}
\hline No. & \multicolumn{1}{|c|}{ Sampel } & Air $\%$ & Abu $\%$ & Protein $\%$ & Lemak \% & K.Hidrat \% \\
\hline 1 & $100 \%$ daging tuna & 20,18 & 8,50 & 62,35 & 1,76 & 7,21 \\
\hline 2 & $\begin{array}{l}75 \% \text { daging tuna: } 25 \% \\
\text { tulang tuna }\end{array}$ & 11,02 & 38,27 & 40,67 & 3,66 & 6,38 \\
\hline 3 & $\begin{array}{l}50 \% \text { daging tuna: } 50 \% \\
\text { tulang tuna }\end{array}$ & 17,40 & 25,73 & 45,40 & 1,00 & 9,71 \\
\hline 4 & $100 \%$ tulang tuna & 5,73 & 65,83 & 17,18 & 5,04 & 6.22 \\
\hline 5 & $100 \%$ daging Cakalang & 7,04 & 4,86 & 66,38 & 5,58 & 16,14 \\
\hline
\end{tabular}




\begin{tabular}{c|l|c|c|c|c|c}
\hline 6 & $\begin{array}{l}75 \% \text { daging Cakalang: } \\
25 \% \text { tulang Cakalang }\end{array}$ & 8,09 & 9,98 & 62,74 & 7,98 & 11,21 \\
\hline 7 & $\begin{array}{l}50 \% \text { daging Cakalan: } \\
50 \% \text { tulang cakalang }\end{array}$ & 8,16 & 16,50 & 53,34 & 3,36 & 18,64 \\
\hline 8 & $100 \%$ tulang cakalang & 6,95 & 35,15 & 32,27 & 8,00 & 17,63 \\
\hline 9 & Ikan puri & 4,33 & 32,96 & 47,34 & 3,46 & 11,91 \\
\hline 10 & $\begin{array}{l}\text { Ikan puri + kepala ikan } \\
\text { puri }\end{array}$ & 9,34 & 15,85 & 59,79 & 6,00 & 9,02 \\
\hline 11 & Ikan sarden & 9,40 & 12,68 & 58,89 & 5,50 & 13,53 \\
\hline 12 & Ikan sarden kering & 9,15 & 16,64 & 56,60 & 8,06 & 9,55 \\
\hline 13 & Sisik ikan merah*) & 10,78 & 43,54 & 28.49 & 5,37 & 11,83 \\
\hline
\end{tabular}

Sumber : Hasil Uji Proksimat di Lab. Nutrisi Politani Pangkep; *): Talumepa, dkk., (2016)

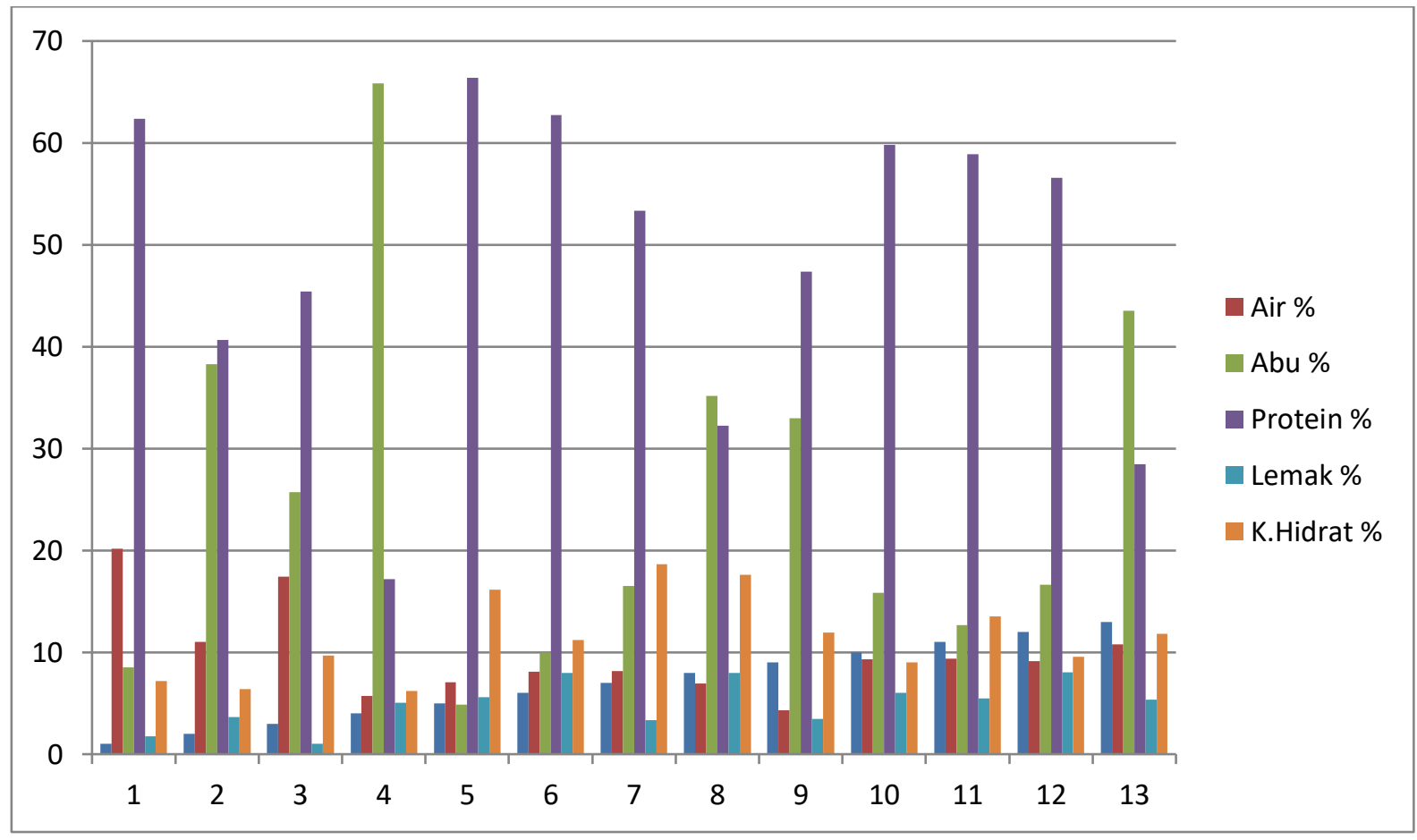

Gambar 2. Grafik Uji Proksimat Tepung Ikan Berbahan Limbah Ikan

Pemilihan sampel bahan limbah ikan pada Tabel 1 di atas didasarkan pada persyaratan bahan pakan yang dikemukakan oleh Afrianto dan Liviawati (2005). Tepung berbahan limbah ikan di TPI Jembatan Puri (Jempur) memiliki kisaran protein yang tinggi berkisar antara 48,57\%, kadar air yaitu 9,81\%, kadar abu yaitu 25,11\%, kadar lemak berkisar antara 4,98\%, serta kadar karbohidrat mencapai 11,46\%. Hal ini sesuai dengan pendapat Leke dan Sjofjan (2012) bahwa limbah ikan cakalang dengan mencampurkan pakan basal dengan limbah ikan 
cakalang sebesar 20\% memiliki nilai protein 22,07\%, Sitompul (2004) yang menyebutkan bahwa nilai protein berkisar antara 40,01-55,80\%, serta Boniran, (1999) mengatakan bahwa tepung ikan yang baik memiliki kandungan protein kasar 58-68\%.

Berdasarkan jenis ikan seperti disajikan pada Gambar 2 di atas, nilai kandungan yang diperoleh pada tepung berbahan beserta limbahnya berkisar antara 17,18 - 62,35\%. Untuk kadar protein pada ikan cakalang berkisar antara 32,27 - 66,38\%. Untuk kadar protein tepung berbahan ikan teri dan limbah kepala ikan teri yaitu antara 47,54- 59,79\%. Nilai protein pada tepung berbahan ikan sarden berkisar antara 56,6-58,89\% (Tabel 1). Serta nilai protein sisik ikan kakap merah (Lutjanus sp.) yaitu 28.49\% (Talumepa, dkk., 2016). Faktor yang menyebabkan tingginya nilai protein pada tepung ikan dikarenakan adanya pengurangan kadar air pada saat pembuatan bahan tepung ikan. Hal ini sesuai dengan hasil penelitian Ekawati (2014) yang mengatakan bahwa kadar protein ikan cakalang goreng lebih tinggi karena kadar airnya lebih rendah dibandingkan ikan cakalang segar. Semakin rendah kadar air maka konsentrasi protein di dalam bahan semakin pekat, sehingga persentasenya akan lebih besar. Leke dan Sjofjan, (2012) mengatakan bahwa limbah ikan cakalang dapat digunakan sebagai alternatif bahan pakan lokal sumber protein hewani untuk pakan ayam kampung. Penggunaan tepung limbah pengalengan ikan pelagis besar seperti tuna dan cakalang dapat digunakan dalam ransum sampai 14\% (Leke dan Sjofjan, 2012), serta Baye dkk., (2015). Trilaksani, Salamah, dan Nabil, (2006) mengatakan bahwa kadar protein dari tepung tulang ikan yang dihasilkan mengandung kalsium tertinggi 39,24\% dan fosfor 13,66 \% yang diperoleh dari kombinasi perlakuan autoclaving 2 (dua) jam dan perebusan 3 (tiga) kali. Kadar air pada tepung tulang sebesar 5,60\%, abu $81,13 \% \mathrm{bb}$, protein $0,76 \% \mathrm{bb}$ dan lemak 3,05\%bb. Hal ini berbeda dengan hasil penelitian yang diperoleh bahwa kadar protein pada Tabel 1 yaitu rata-rata kadar protein sebesar 48,57\%\%. Penggunaan bahan limbah ikan diharapkan dapat mengurangi beban dari kegiatan pelelangan ikan di TPI Jembatan puri berupa hasil olahan sampingan dari limbah ikan tuna, ikan cakalang, ikan puri, dan ikan sarden, serta sisik ikan merah. 
Penggunaan limbah ikan sudah memenuhi kriteria untuk bahan pakan dikarenakan limbah ikan tidak dimanfaatkan oleh manusia. Hal ini sesuai dengan pendapat Afrianto dan Liviawaty (2005) yang mengatakan bahwa bahan baku pakan sebaiknya lebih banyak mengandalkan potensi limbah yang tersedia di sekitar lokasi budidaya perikanan. Selain itu, pertimbangan ekonomi bahan baku yang digunakan dalam pembuatan pakan ikan umumnya mempunyai kualitas lebih rendah dibandingkan dengan bahan baku untuk produk pangan dikarenakan bersumber dari bahan pertanian yang memiliki serat yang tinggi seperti dedak padi yaitu $7,23 \%$ atau bungkilkopra sebesar 11,5\% (Fahrizal, 2011) dibanding dengan limbah hasil perikanan seperti ikan cakalang yang memiliki kadar protein hingga $60 \%$.

\section{Kesimpulan}

Kesimpulan dari hasil penelitian menunjukkan bahwa tepung berbahan limbah ikan berdasarkan jenis ikan tuna, ikan cakalang, ikan teri, ikan sarden serta sisik ikan kakap merah layak untuk digunakan sebagai bahan pakan berdasarkan kriteria bahan baku meliputi kandungan protein serta ketersediaan bahan untuk pembuatan tepung ikan.

\section{Ucapan Terima Kasih}

Terima kasih untuk Direktorat Riset dan Pengabdian Masyarakat (DRPM), Direktorat Jenderal Penguatan Riset dan Pengembangan, Kementerian Riset, Teknologi dan Pendidikan Tinggi, Sesuai Surat Perjanjian Penugasan Pelaksanaan Penelitian Nomor: 12/K14/AK/Kontrak Penelitian/2018, Tanggal 19 Februari 2018 atas bantuan pendanaan penelitian.

\section{Daftar Pustaka}

Afrianto. E., dan E. Liviawaty., 2005. Pakan Ikan. Pembuatan, Penyimpanan. Pengujian. Pengembangan. Penerbit Kanisius.

BPS Papua Barat, 2018. Provinsi Papua Barat Dalam Angka. Papua Barat Province In Figures. Katalog 1102001.91. 432 halaman. 
Baye, A., F. N. Sompie., B. Bagau., M. Regar., 2015. Penggunaan Tepung Limbah Pengalengan Ikan Dalam Ransum Terhadap Performa Broiler. Fakultas Peternakan. Universitas Sam Ratulangi. Jurnal Zootek ("Zootek" Journal ) Vol. 35 No. 1, Januari 2015. ISSN 0852 -2626; halaman 96-105.

Boniran, S., 1999. Quality Control Untuk Bahan Baku dan produk Akhir Pakan Ternak. Kumpulan Makalah Feed Quality Management Workshop American Soybean Association dan Balai Penelitian Ternak. Hlm 2-7.

Departemen Perikanan dan Kelautan, 2011. Laporan perikanan. Departemen Perikanan dan Kelautan Kota Sorong. Sorong.

Departemen Perikanan dan Kelautan, 2017. Laporan Tahun 2016. Dinas Perikanan dan Kelautan Pemerintah Kota Sorong.

https://finance.detik.com/berita-ekonomi-bisnis/d-2794634/importepung-ikan-capai-rp-57-triliuntahun. 2015. Dikutip pada Tanggal 05/09/2018, pada pukul : 11:24 AM.

Dewi. S.N., dan S. Ruqoyah. 2014. Cara Perikanan Nusantara Bangun Kembali Usaha Di Sorong, Papua. Berita Bisnis. http:/ / m.viva.co.id/berita/bisnis /534763-cara-perikanannusantara-bangun-kembali-usaha-di-sorong -papua. Dikutip pada 24 April 2017, pada pukul 12:10 WIT.

Fahrizal. A., 2011. Pemanfaatan Bungkil Kopra Sebagai Pakan Subtitusi Pada Pembesaran Ikan Bandeng (Chanos-chanos) Di Keramba Jaring Apung. Skripsi. Jurusan Budidaya Perairan. Fakultas Perikanan dan Ilmu Kelautan. Universitas Muslim Indonesia. 36 halaman.

Leke. J. R., dan O. Sjofjan, 2012. Nilai Kecernaan Zat-Zat Gizi Limbah Ikan Cakalang (Katsuwonus pelamis L.) Pada Ayam Kampung (Nutrients Digestibility of Waste Cakalang (Katsuwonus pelamis L.) on Native Chicken). Workshop Nasional Unggas Lokal 2012. Halaman 129-134.

Munthe. I., M. Isa., Winaruddin., Sulasmi., Herrialfian., dan Rusli., 2016. Analisis Kadar Protein Ikan Depik (Rasbora tawarensis) Di Danau Laut Tawar Kabupaten Aceh Tengah. Protein Content Analysis of Depik (Rasbora tawarensis) In Laut Tawar Lake Aceh Tengah. Jurnal Medika Veterinaria. 10(1): 67 - 69.

Peraturan Menteri Kelautan dan Perikanan No. 56 Tahun 2014. Penghentian Sementara (Moratorium) Perizinan Usaha Perikanan Tangkap Di Wilayah Pengelolaan Perikanan Negara Republik Indonesia. $3 \mathrm{hlm}$. 
Satwas PSDKP Sorong, 2017. Laporan Rekapitulasi Kedatangan Dan Keberangkatan Kapal Perikanan (Pengangkut/Penangkap) Ijin Pusat/Propinsi/ Kabupaten/Kota Di Pelabuhan Perikanan Pantai Sorong. Laporan Ketaatan 2017.

Sitompul. S., 2004. Analisis Asam Amino dalam Tepung Ikan dan Bungkil Kopra. Buletin Teknik Pertanian 9(1): 33-37.

SNI 01-2715-1996/Rev.92. Tepung Ikan/Bahan Baku Pakan. Dewan Standardisasi Nasional. 7 halaman.

Talumepa. A. C. N., P. Suptijah, S. Wullur, dan I. F. M. Rumengan. Kandungan kimia dari sisik beberapa jenis ikan laut. Jurnal LPPM Bidang Sains dan Teknologi. 3(1): 27-33.

Trilaksani. W., E. Salamah., dan M. Nabil., 2006. Pemanfaatan Limbah Tulang Ikan Tuna (Thunnus sp.) Sebagai Sumber Kalsium Dengan Metode Hidrolisis Protein. Buletin Teknologi Hasil Perikanan. 9(2): 34-45.

USAID SEA Project, 2018. Laporan Enumerator Kabupaten Sorong Selatan. USAID Sustainable Ecosystems Advanced (SEA Project). Indonesia. USAID. From The American People. 